\title{
МІЖНАРОДНИЙ АСПЕКТ РОЗВИТКУ \\ БАНКІВСЬКОГО СЕКТОРУ: СУЧАСНІ ТЕНДЕНЦІї, ЧИННИКИ ТА ПРОБЛЕМИ
}

\section{Дятлова Юлія Володимирівна}

доктор економічних наук, доцент, Донецький державний університет управління м. Маріуполь, Україна

ORCID: 0000-0001-7982-2493

yuliyadyatlova25@gmail.com
Надіслано:

13.02.2021

Рецензовано:

20.02.2021

Прийнято:

15.03.2021

Актуалізація дослідження обумовлена необхідністю вирішення важливої наукової та прикладної проблеми розвитку банків 3 національним капіталом за присутності іноземного капіталу в банківському секторі країни. Мета дослідження полягає у систематизації новітніх тенденцій розвитку банківського сектору у міжнародному та національному аспектах, розробленні наукових положень, конкретизації чинників i проблем. Для досягнення мети використано еволюційний підхід, абстрактно-логічний аналіз, метод систематизації та узагальнення. У результаті дослідження поглиблено наукові уявлення про сучасні тенденції та чинники розвитку банківського сектору. Зокрема, сформульовано положення щодо міжнародного аспекту сучасних тенденцій розвитку банківського сектору. Відзначено світові тенденції щодо експансії ринків фінансових послуг іноземними банками, еволюційний розвиток транснаціональних банків. Встановлено, що основною тенденцією $€$ зростання присутності іноземних банків у національних банківських секторах країн за кількістю та активами, особливо в країнах 3 економікою, яка розвивається або трансформується. Визначено новітні етапи розвитку банківського сектору України, особливості тенденцій, які повинні бути враховані в політиці та стратегії центрального банку, а також банками 3 вітчизняним капіталом. Показано, що більш низька надійність банків 3 вітчизняним капіталом порівняно з іноземними банками $є$ деструктивним чинником. Вирішення проблеми сприятиме підвищенню довіри до вітчизняних банків, а на цих засадах їх розвитку через збільшення активів.

Ключові слова: банківський сектор; світові тенденції розвитку; наявність іноземних банків; особливості в банківському секторі країн;

(СДятлова Ю. В. 2021 


\section{Міжнародні відносини: теоретико-практичні аспекти \\ Випуск 7 (2021) \\ ISSN (print) 2616-745X; ISSN (online) 2616-7794}

фактори розвитку банків з національним капіталом.

\section{Вступ}

В умовах глобалізації, які сприяють посиленню конкуренції та поширенню криз, стабільність функціонування національної економіки обумовлена стійкістю фінансової системи країни. Розвинута банківська система $€$ гарантом фінансової стабільності і безпеки в економічній сфері, особливо для країн з банкоцентричною фінансовою системою. Україна є однією з таких країн. Розвиток банківського сектору України $є$ пріоритетним з точки зору забезпечення фінансовими ресурсами суб'єктів господарювання різних галузей і сфер, а також здійснення впливу на соціально-економічні процеси в країні.

Банківський сектор як вагому складову національної фінансової системи відрізняє чутливість до глобальних фінансових кризових явищ і значна залежність від кон'юнктури на світових ринках. Крім того, лібералізація економічної політики та відкритий доступ до ринку фінансових послуг України створює умови, в яких банки з національним капіталом можуть не витримати конкуренції з банками іноземних груп. Тому розвиток банківського сектору $\epsilon$ нагальною потребою і досвід країн за схожих тенденцій слугуватиме прикладом при формуванні стратегії в фінансовій сфері.

\section{Аналіз останніх досліджень і публікацій}

Значення банківської системи для розвитку економіки аргументовано теоретично i підтверджено на практиці. Це положення доведено представниками різних наукових шкіл, наприклад, в концепції А.Сміта, Д. Рікардо, І. Ріссера щодо ефективного розміщення ресурсів в економічній системі, а також в концепції А. Пігу, Дж. Герлі, Р. Голдсмита, У. Зілбера, Е. Коена, Е. Шоу, М. Фрідмена про стимулювання економічного росту за допомогою змін у пропозиції грошей. Вирішення проблем в банківській сфері викладено в працях П. Аллена, Е. Долана, Р. Міллера, П. Роуза, Дж. Сінкі.

Проблемам, що виникають у процесі розвитку банківської системи в глобалізаційній економіці, присвячені праці видатних вітчизняних вчених, таких як М. Алексеєнко, Я. Белінська, А. Гальчинський, В. Геєць, О. Дзюблюк, А. Єпіфанов, Т. Карчева, В. Коваленко, В. Коваль, В. Лук'янов, В. Міщенко та ін. y наукових дослідженнях аналізуються важливі теоретичні і практичні питання розвитку банківського сектору, у тому числі в конкурентних умовах господарювання. Однак процеси, пов'язані з прискоренням змін у світовій фінансовій системі та зростанням конкуренції через присутність на національному ринку іноземних банків, потребують теоретичного та методологічного доопрацювання та розроблення наукових положень. 


\section{Формулювання цілей статті}

Головна мета дослідження - систематизувати новітні тенденції розвитку банківського сектору у міжнародному аспекті, розробити наукові положення, конкретизувати чинники i проблеми на національному рівні. У цьому ключі необхідно відстежити еволюційний розвиток транснаціональних банків у процесі експансії ринків фінансових послуг іноземними банками, визначити головну тенденцію та ї̈ особливості щодо країн 3 різним рівнем економічного розвитку. Значну увагу необхідно зосередити на пострадянських країнах, зокрема Україні, виокремити етапи та чинники розвитку банківського сектору, визначити проблеми. Це дозволить поглибити наукове підгрунтя розвитку банківського сектору для вирішення прикладних завдань.

\section{Виклад основного матеріалу дослідження}

Витоки вільного переміщення капіталу, поряд з товарами, послугами та робочою силою, започатковані в правовому полі Римським договором від 1957 р. для реалізації європейської економічної інтеграції. У світових масштабах провідниками фінансової глобалізації стали банки США.

На думку багатьох учених, ці процеси мають такі позитивні ефекти як інтенсифікація притоку іноземного капіталу в різні сфери економіки країни, використання банками передового досвіду з запровадження нових фінансових інструментів, розширення переліку банківських послуг. Однак експансія світового фінансового ринку, i перш за все, транснаціональними банками сприяє підвищенню міжбанківської конкуренції в міжнародному, а також національному аспектах.

Учені приділяють увагу тенденціям щодо експансії ринків фінансових послуг іноземними банками, зокрема транснаціональними, у світі та в Україні. Так, аналіз міжнародної діяльності транснаціональних банків (ТНБ) з різних регіонів і країн світу на ринках послуг, які надаються національними банками в їх країнах, відкриття філій іноземними банківськими групами дозволило систематизувати уявлення про еволюційний їх розвиток, що здійснювався за рахунок набуття ними конкурентних переваг. Етапи еволюційного розвитку діяльності ТНБ протягом другої половини минулого століття і на поч. 2000-х рр. свідчать, що масштаби їх діяльності збільшилися в десятки разів (Panchenko, Fursova, Koval, 2012, p.11). Починаючись із США, транснаціональна «лихоманка» охопила ринки Європи, Японії, а в 2000-хрр. також таких країн як Великої Британія, Франція, Іспанія, Німеччина, Китай. Конкурентні переваги набувалися переважно за рахунок диверсифікації послуг.

(С) Дялова Ю. В. 2021 


\section{Міжнародні відносини: теоретико-практичні аспекти \\ Випуск 7 (2021) \\ ISSN (print) 2616-745X; ISSN (online) 2616-7794}

Еволюційний розвиток транснаціональних банків у міжнародному аспекті може бути охарактеризований за такими етапами. У 50-60-тірр. ХХ ст. домінували ТНБ США за рахунок інвестування країн ОПЕК та кредитування країн, які були головними імпортерами нафти. У 70-80-ті рр. відзначено домінування ТНБ Японії завдяки концентрації фінансового капіталу та формуванню наднаціональних банківських установ. У 90-тірр. експансія на міжнародних ринках обумовлена поглибленням валютної інтеграції. Починаючи 3 2000-их рр. розвиток транснаціональних банків характеризується прискоренням процесу концентрації й централізації капіталу через злиття і поглинання, а також глобалізацією банківських операцій, реструктуризацією банківських мереж, запровадженням новітніх фінансових технологій. Вважається, що в 50-60-ті рр. ступінь банківської глобалізації був низьким, в 70-80-тірр. - середнім, а починаючи 3 2000-х рр. - високим. Отже, ТНБ США, Великої Британії, Німеччини, Франції, Іспанії, Китаю та Японії, які сформувалися на базі найбільших банків - лідерів національного ринку позикового капіталу.

За версією The Banker 2020, ТОП-5 найбільших ТНБ світу очолюють чотири китайські та американський банк (табл. 1). Рейтингові та аналітичні агентства щорічно складають рейтинги надійних, прибуткових та успішних банків, проте критерії вибору відрізняються. Але їх дані свідчать, що китайські банки залишаються найбільшими корпораціями у світі. Так, за даними Forbes, до ТОП-10 найбільших публічних компаній увійшли п’ять банків з Китаю, що є світовим визнанням його банківської системи.

Таблищя 1

Т0П-10 найбільших банків світу

\begin{tabular}{|c|l|c|c|c|}
\hline Ранг & \multicolumn{1}{|c|}{ Назва банку } & $\begin{array}{c}\text { Капітал } \\
\text { першого рівня, } \\
\text { млрд дол. }\end{array}$ & $\begin{array}{c}\text { Сукупні } \\
\text { активи, } \\
\text { млрд дол. }\end{array}$ & $\begin{array}{c}\text { Прибуток до } \\
\text { оподаткування } \\
\text { млрд дол. }\end{array}$ \\
\hline 1 & $\begin{array}{l}\text { Industrial and Commercial Bank of } \\
\text { China }\end{array}$ & 380,189 & 4307,502 & 56,050 \\
\hline 3 & China Construction Bank & 316,122 & 3638,950 & 46,723 \\
\hline 2 & Agricultural Bank of China & 277,608 & 3559,126 & 38,137 \\
\hline 4 & Bank of China & 258,431 & 3257,474 & 35,858 \\
\hline 5 & JP Morgan Chase \& Co & 258,431 & 3257,474 & 35,858 \\
\hline
\end{tabular}


В Україні на фінансовому ринку представлені Industrial and Commercial Bank of China (представництво в 2004 p.), JPMorgan Chase \& Со (присутній 3 1984 p.), Hongkong \& Shanghai Banking Corporation (функціонує дочірній банк), Mitsubishi UFJ Financial Group (працює з 2011 р.), BNP Paribas Personal Finance (працює 32004 р., володіє акціями «УкрСиббанку»), UBS Group AG (представництво з 1995 р., дочірня фінансова установа - 32009 р.). Також в Україні працюють й інші транснаціональні банки, які мають високий світовий рейтинг, наприклад Crédit Agricole (Франція), Citigroup (США), ING Group (Нідерланди), Deutsche Bank (Німеччина), Intesa Sanpaolo (Італія).

Слід також зазначити, що в Україні відсутні власні ТНБ. За даними Національного банку України, сукупні активи банків у 2015 р. становили близько 3 \% активів британського банку Royal Bank of Scotland.

Науковцями визначено етапи входження іноземних банків на ринок банківських послуг України з 1991 по 2010 pp. (Kornyliuk, Ivasiv, Dyba, 2012).

Перший етап - 1991-1994 pр. На початку створення банківської системи України через відсутність досвіду регулювання банківської діяльності в ринкових умовах на ринку банківських послуг з'явився спекулятивний капітал банків Російської Федерації, Латвії та 3 офшорних зон. Процес обтяжувався валютними спекуляціями та нелегальним вивезенням капіталу з України. Тому НБУ в 1994 р. запровадив обмеження щодо частки іноземного капіталу в статутному капіталі банків до 15 \%, а також заборонив діяльність філій іноземних банків.

Другий етап - 1995-1998рp. Тактика проникнення іноземних банків на український ринок банківських послуг проходила під мотивом обслуговування зовнішньоекономічних операцій нерезидентних суб'єктів господарювання. Створені в Україні іноземні банки також забезпечували вихід вітчизняних банківських установ на міжнародні ринки капіталу. Фінансова криза 1998 р. спричинила відплив іноземного капіталу та вихід іноземних банків 3 ринку.

Третій етап - 1999-2004 pp. Відповідно політиці лібералізації банківського регулювання знято обмеження на частку присутності іноземного капіталу в статутному капіталі банку, що обумовлено зменшенням капіталізації банківської системи і недостатністю довгострокових кредитних ресурсів. Разом 3 цим проводилися заходи щодо очищення банківської системи від банків, які проводили спекулятивні операції. Кількість іноземних банків скоротилася. Шляхом придбання невеликих українських банків до банківського ринку отримали доступ «Альфа-Банк» (Російська Федерація)

(СДятлова Ю. В. 2021 


\section{Міжнародні відносини: теоретико-практичні аспекти \\ Випуск 7 (2021) \\ ISSN (print) 2616-745X; ISSN (online) 2616-7794}

та «ПроКредит Банк» (Німеччина). Однак несприятливий інвестиційний клімат, політико-правова нестабільність, низька платоспроможність юридичних і фізичних осіб стримували прихід нових іноземних банківських груп.

Четвертий етап - 2005-2008 pp. Активна експансія зумовлена загальним економічним зростанням. На український ринок масово виходять ТНБ шляхом поглинань системних вітчизняних банківських установ, які здебільшого мали широку територіальну мережу структурних підрозділів. Тільки у 2005 р. обсяг угод зі злиття та поглинання становив більше 1,5 млрд дол. США (Vozna, 2013). У 2006-2008 pp. іноземні банківські групи купували банки, які мали ліцензії: ВТБ Банк (Росія) придбав 98 \% акцій банку «Mрія», Eurobank EFG (Швейцарія) став власником Універсал Банку, Piraeus Bank (Греція) - Міжнародного комерційного банку. Умови для експансії створила лібералізація регулювання банківської діяльності через вступ України до Світової організації торгівлі. Кредитні ресурси значно зросли через дешеві валютні ресурси ТНБ, співвідношення активів банків до ВВП збільшилося до 63,2 \% (Stechyshyn, 2017, p. 228).

П’ятий етап - 2008-2010 рр. У цей період, що характеризується фінансовою кризою та посткризовим відновленням економіки, іноземні банки проводять антикризову політику для утримання на банківському ринку України за рахунок використання банківського капіталу материнської компанії. Не всі іноземні банки витримали девальвацію української валюти, спад кредитування та зростання проблемної заборгованості. Відтік іноземного та вітчизняного капіталу з ринку привів до збільшення частки банків 3 Російської Федерації та Німеччини в загальному статутному капіталі банківського сектору. Іноземні банки скорочують територіальну мережу, однак продовжують фокусувати діяльність на обслуговуванні корпоративних клієнтів.

На нашу думку, надалі етапи розвитку банківського сектору можуть бути визначені наступним чином.

Шостий етап - 2010-2014 рр. Після виходу з кризи банківський сектор функціонував відносно стабільно 3 достатньою ліквідністю, чому сприяли зміни в правовій базі (Pro vnesennia zmin..., 2010). Розвиток банківського сектору обмежували такі чинники як недовіра до банківської системи, скорочення через це депозитних ресурсів і подорожчання кредитів, що не дозволило банківському сектору відновитися і мати активи, які б задовольняли потреби економіки. 
Сьомий етап - 2014 р. і дотепер. У зв'язку з політичною нестабільністю та військовими діями показники банківської системи погіршилися, зросла кількість неплатоспроможних банків, а криза платежів трансформувалася в банківську кризу, яка визнана системною. Чинниками таких змін були: погіршення стану державних фінансів, депресивність ділової активності, недовіра до банківської системи та гривні, споживча інфляція, девальвація національної валюти. Розпочате в цей час реформування тільки погіршило стан банківського сектору. Значними подіями були: націоналізація ПАТ КБ «Приватбанк» наприкінці 2016 р., заборона банкам 3 російським капіталом виводити кошти за межі України на користь пов'язаних осіб. $\mathrm{У}$ цей період частка банків з іноземним капіталом має значні коливання.

Аналіз праць учених з України, Білорусії, Росії, зокрема таких як О. Дзюблюк (Dziubliuk, 2012), Н. Наливайко (Nalivayko, 2012), А. Михайлов (Mikhailov, 2018) та ін., підтверджує необхідність досліджень проблеми розвитку національного банківського сектора за присутності іноземних банків. Систематизація досвіду країн і встановлення сучасних тенденцій $є$ нагально потребою.

Міжнародний аспект банківської діяльності досліджувався Міжнародним валютним фондом (Claessens, Horen, IMF, 2012) і Світового банку (Global Financial..., 2017/2018). Дослідження Міжнародного валютного фонду охопило банківські системи 137 країн за показниками часток іноземних банків у загальній чисельності банків у країні (1995-2009) і часток іноземного капіталу в загальному обсязі активів банківського сектору країни (2004-2009). Дослідження Світового банку з глобального фінансового розвитку проведено за даними аналогічними показниками одного року (2014 ). Значення та зміни цих показників за країнами, групами країн, регіонами і загалом у світі дозволяють визначити певні тенденції та чинники (рис. 1).

Ситуація у посткризовому 2014 р. для певних груп країн радикально не змінилася. У групі економічно розвинених країн Японія продовжує політику протекціонізму - частки іноземних банків мінімальні за обома показниками, хоча в загальній кількості їх чисельність збільшилась. У банківському секторі Італії та Франції частка іноземного капіталу в активах залишилася незмінною, відбулось незначне зменшення показника у Великій Британії (із $15 \%$ у 2009 р. до 14 \% у 2014 р.), але найбільшою мірою - у США (із 18 \% до $11 \%$ ). Ймовірно, відтік іноземного капіталу спричинила як криза 2008 р., так і зміни положень, прийнятих Федеральним банком США.

С.Дятлова Ю. В. 2021 


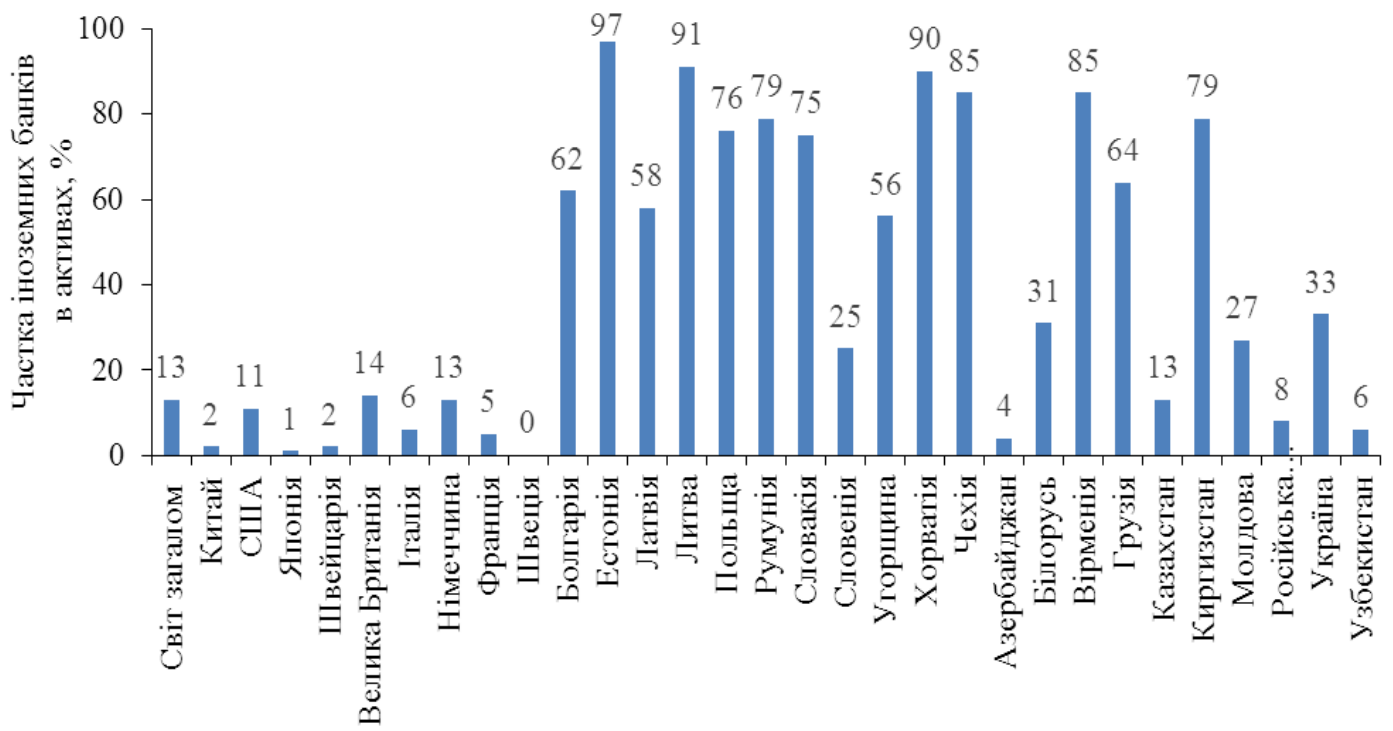

$\mathbf{a}$

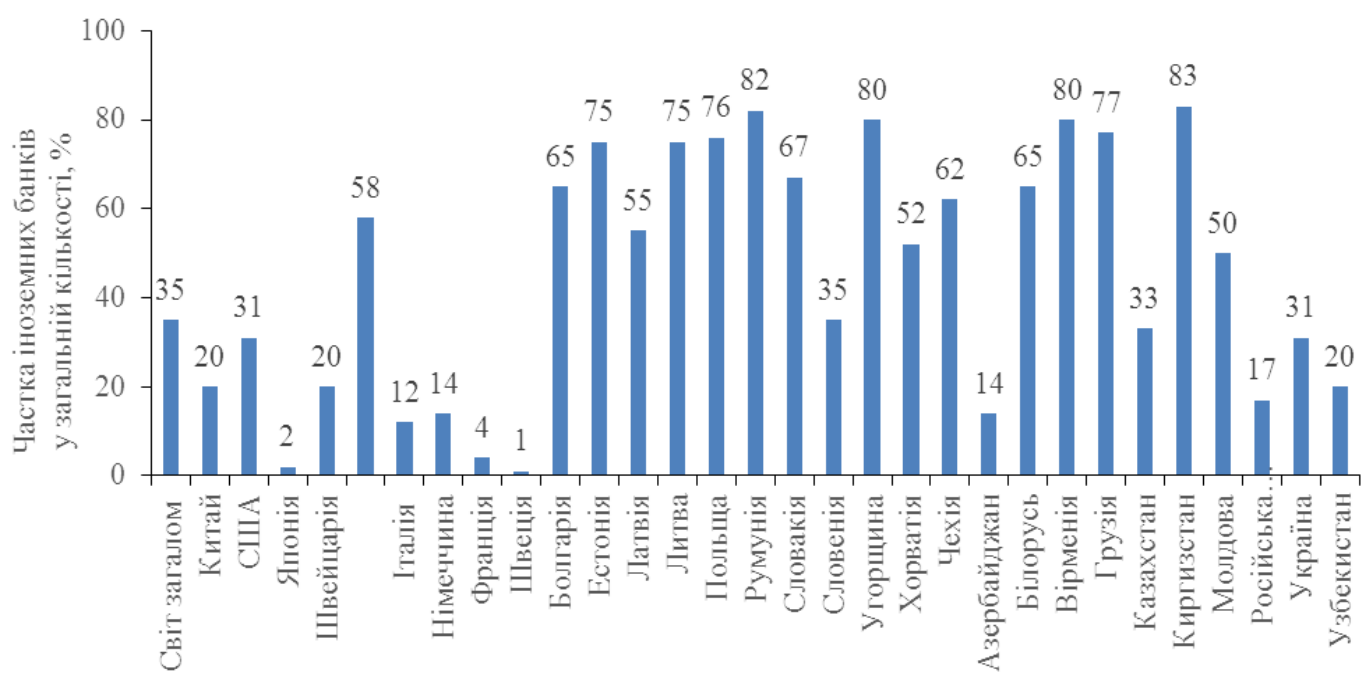

б

Рис. 1. Присутність іноземних банків у банківських системах країн за активами (а) та кількістю (б) за даними Світового банку 
В економічно розвинених країнах частка іноземних банків у загальній кількості банків набагато більше, ніж їх частка в активах. Так, у США частка іноземних банків у загальній їх кількості дорівнює $31 \%$ (у 2009 р. - 32\%), тобто практично кожне третя банківська установа - іноземного походження, але частка їх капіталу майже у 3 рази менша. Ще більше розрізняються показники по банківському сектору Великої Британії: частка іноземних банків за чисельністю становить $58 \%$ (у 2009 р. - $57 \%$ ) при їх частці в капіталі у 14 \%, тобто у 4 рази меншій. По Швейцарії показники розрізняються в 5 разів, по Австралії - майже в 20, у їі банківській системі іноземні банки контролюють $2 \%$ активів при частці в $38 \%$ за кількістю установ. Це вказує на той факт, що конкурентні позиції іноземного капіталу слабші, ніж банків приймаючої країни.

Аналіз тенденцій свідчить про чинник значного впливу іноземного капіталу на розвиток національних банківських секторів через переважно високий рівень їхньої участі в активах колишніх соціалістичних і пострадянських держав.

У державах - нових членах ЄС політика лібералізації щодо доступу до ринку банківських послуг призвела до значного зростання конкуренції, а 3 огляду на зростаючу потребу в активах, національні банки погано утримують конкурентні позиції (значення обох показників більше $60 \%$ ). Аналогічна ситуація і в країнах пострадянського простору, що вступили до ЄС: активи банківського сектора Естонії і Литви - це на 90 \% і більше іноземний капітал. Значним $€$ показник і по банківському сектору Латвії.

Із пострадянських держав залишився значним вплив іноземного капіталу в банківському секторі Вірменії, Грузії, Киргизстану. Туркменістан і Таджикистан не досліджувалися. Відбулося зростання іноземного капіталу в банківських активах Білорусії (з $18 \%$ до $31 \%$ ). А ось в Україні, у зв'язку з воєнно-політичною ситуацією, частка активів іноземних банків стала меншою у 2 рази. При цьому з переходом на міжнародні стандарти значно зменшилася кількість банків, в основному за рахунок вітчизняних.

У банківському секторі Російської Федерації частка активів іноземного походження знизилася (із $12 \%$ у 2009 р. до $8 \%$ в 2014 р.). За даними Федерального банку Росії, на кінець 2015 р. ця частка становила 12,5\%. Частка активів нерезидентів за всіма кредитними організаціям протягом останніх років була на рівні $25 \%$, а в 2015 р. - нижче $20 \%$. Квота щодо участі іноземного капіталу збільшилася до 50 \% від сукупного статутного

С.Дятлова Ю. В. 2021 


\section{Міжнародні відносини: теоретико-практичні аспекти \\ Випуск 7 (2021) \\ ISSN (print) 2616-745X; ISSN (online) 2616-7794}

капіталу кредитних організацій (0 vnesenii izmenenii..., 2015), але іноземні інвестори її не вибрали в повному обсязі.

У звіті Світового банку (Global Financial..., 2017/2018) наведено й показник кількості країн, які приймають національні банки (рис. 2). Цей показник $є$ значним для економічно розвинених країн і мінімальний як для країн - нових членів ЄС, так і держав пострадянського простору (банки в 1-2 країнах). Найбільш значним є показник для банківського сектору Росії. Слід зазначити, що банки з України мають філії у чотирьох країнах, з Казахстану - у 5 країнах.

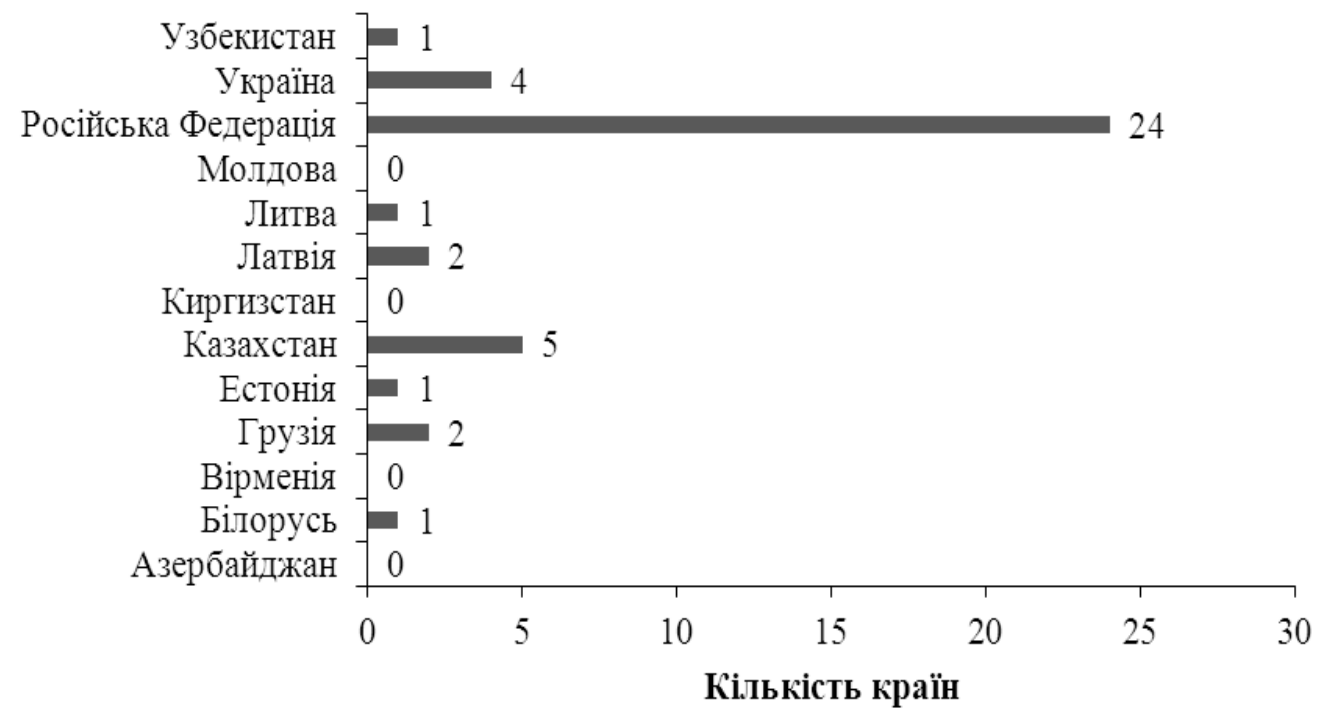

\section{Рис. 2. Кількість країн, в яких відкрито філії національних банків}

Аналіз тенденцій розвитку банківського сектору як загальних світових, так і по країнах (Diatlova, 2018a), дозволив констатувати поширення присутності іноземних банків у національних банківських системах та сформулювати положення, які стосуються сучасних тенденцій розвитку банківського сектору та виокремити процеси інтерналізації, що $\epsilon$ характерними для країн з економікою, що розвивається та трансформується (рис. 3).

При формулюванні основних тенденцій автор виходить 3 поняття інтерналізації як одного з визначальних процесів, через який відбувається зміна умов розвитку в банківському секторі під впливом присутності іноземних банківських установ та іноземних активів у вітчизняних банках (Diatlova, 2018b). 


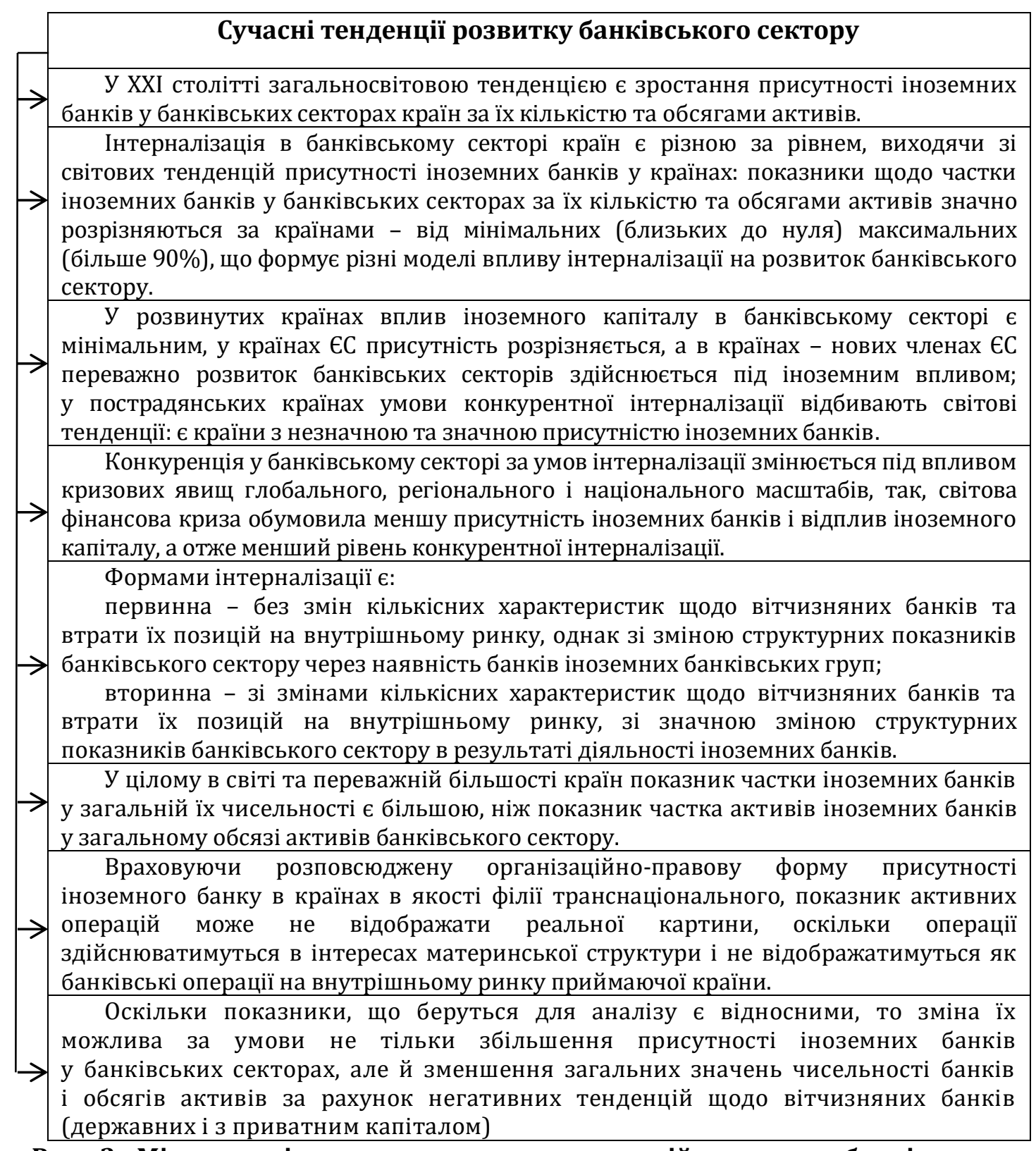

Рис. 3. Міжнародні аспекти сучасних тенденцій розвитку банківського сектору та обгрунтування ролі інтерналізації в ньому

(СДятлова Ю. В. 2021 


\section{Міжнародні відносини: теоретико-практичні аспекти \\ Випуск 7 (2021) \\ ISSN (print) 2616-745X; ISSN (online) 2616-7794}

Основним чинником, що стримує розвиток банківського сектору в Україні є низький рівень довіри до вітчизняних банків. Довіра до банківської системи зростає за умов надійності та фінансової стійкості банківських установ. Надійність банків визначено за тенденцією індексу Bank_FinScore (Renkinh..., 2020) (табл. 2), який оцінюється від одного до 4 балів. Значення індексу обумовлено одиничними індикаторами, що базуються на нормативах НБУ.

Таблиця 2

Індекс Bank_FinScore за групами банків в Україні

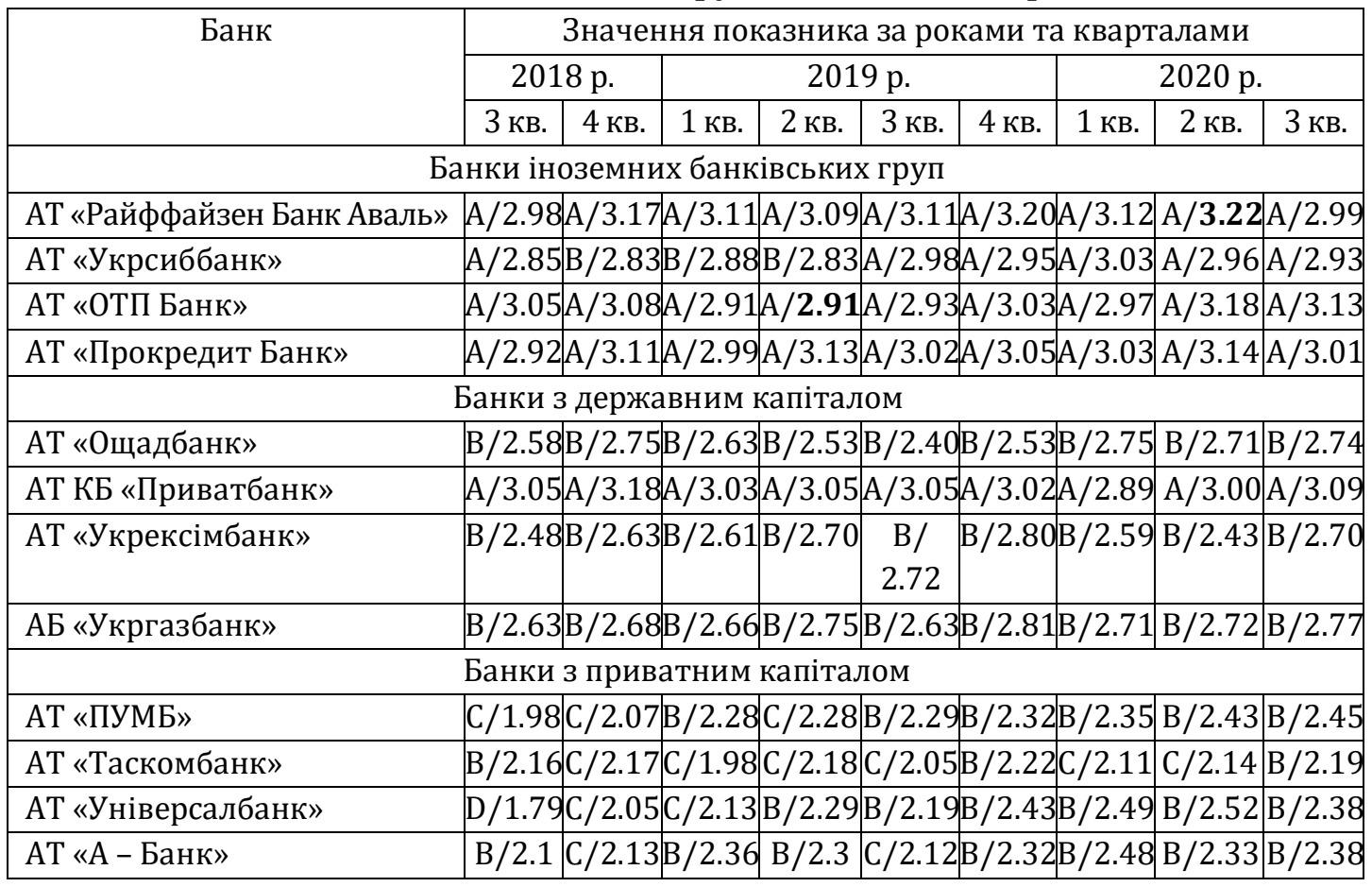

Відзначено стійку тенденцію: найвищий рівень показника мають банки іноземних банківських груп (від 2.83 до 3.22 балів, переважно оцінка А, у деяких випадках - B). Меншу надійність мають банки з державним капіталом (від 2.4 до 3.18, переважно оцінка В, виключення становить Приватбанк з оцінкою A). Найменш надійними є вітчизняні банки з приватним капіталом (від 1.79 до 2.49, оцінки D, C і В), однак тенденція до підвищення надійності є стійкою. 


\section{Висновки}

У роботі систематизовано новітні тенденції розвитку банківського сектору в міжнародному аспекті, визначено їх особливості в країнах. Відзначено етапи світової експансії ринків фінансових послуг іноземними банками, еволюційний характер розвитку транснаціональних банків. На основі результатів дослідження розроблені наукові положення. Визначено, що основною тенденцією $€$ зростання присутності іноземних банків у банківських секторах приймаючих країн, особливо в країнах з економікою, яка розвивається або трансформується. За присутністю іноземних банків країни можна розподілити на три групи. Так, в одних країнах частки іноземних банків за кількістю і за активами є значними і наближаються до 100 \%, в інших 1-5 \%. Більшість країн мають значення обох показників від 5 \% до 70-90 \%. В економічно розвинених країнах банки 3 національним капіталом $\epsilon$ конкурентоспроможними. $\mathrm{y}$ нових членах $€ C$, колишніх соціалістичних країнах, як і в більшості пострадянських держав, показники свідчать про високі конкурентні позиції іноземного капіталу.

Відзначено тенденції присутності іноземних банківських установ та іноземних активів у вітчизняних банках в Україні. Встановлено етапи розвитку банківського сектору України з 2010 р. і дотепер особливості тенденцій. Конкретизовано чинники, показано, що більш низька надійність банків 3 вітчизняним капіталом порівняно 3 іноземними банками $\epsilon$ деструктивним чинником. Вирішення проблеми розвитку банків з національним капіталом за присутності іноземного капіталу в банківському секторі країни сприятиме підвищенню довіри до вітчизняних банків, а на цих засадах їх розвитку через збільшення активів. У подальшому необхідно запропонувати шляхи вирішення проблем за рахунок певних механізмів та інструментів.

\section{References:}

1. 'Bankers without Borders. Global Financial Development Report 2017/2018'. (2018). World Bank Group, [online]. Available at: https://openknowledge.worldbank.org/bitstream/handle/10986/28482/97814648 11487.pdf.

2. Claessens, S., Horen, N. (2012). Foreign banks: trends, impact and financial stability. IMF Working Paper WP/12/10 dated from January 2012. International monetary Fund, [online]. Available at: https://www.imf.org/external/pubs/ft/wp/2012/wp1210.pdf.

(С) Дятлова Ю. В. 2021 


\section{Міжнародні відносини: теоретико-практичні аспекти \\ Випуск 7 (2021) \\ ISSN (print) 2616-745X; ISSN (online) 2616-7794}

3. Diatlova, Yu. V. (2018a). 'Bankivskyi sektor v umovakh konkurentsii z inozemnym kapitalom: systematyzatsiia dosvidu krain i tendentsii' [The banking sector in conditions of competition with foreign capital: systematization of the experience of countries and trends]. Ekonomichnyi prostir [Economic space], no. 140, pp. 5-13.

4. Diatlova, Yu. V. (2018b). 'Internatsionalizatsiia, intehratsiia ta internalizatsiia v bankivskomu sektori: teoretyko-metodolohichni aspekty v konteksti hlobalnoi konkurentsii' [Internationalization, integration and internalization in the banking sector: theoretical and methodological aspects in the context of global competition]. Derzhava ta rehiony. Seriia «Ekonomika ta pidpryiemnytstvo» [State and regions. Economics and Entrepreneurship Series], no. 6(105), pp. 145-151.

5. Dziubliuk, 0. V. (Eds.). (2012). Bankivska systema Ukrainy: stanovlennia $i$ rozvytok $v$ umovakh hlobalizatsii ekonomichnykh protsesiv [Banking system of Ukraine: formation and development in the conditions of globalization of economic processes]. Ternopil: Vector.

6. Kornyliuk, R. V., Ivasiv, I. B., Dyba, O. M. (2012). Inozemni banky v Ukraini: vplyv ta rehuliuvannia [Foreign banks in Ukraine: influence and regulation]. Kyiv: KNEU.

7. Nalivayko, N. N. (2012). Inostrannyi kapital $v$ bankovskoi sisteme respubliki Belarus [Foreign capital in the banking system of the Republic of Belarus], [online]. Available at: http://edoc.bseu.by:8080/bitstream/edoc/14034/2/ Nalivayko_N_N_Ust_rost_2012_S_75-77_ocr.pdf.

8. Mikhailov, A. V. (2018). ,Inostrannyi kapital v bankovskom sektore Rossiiskoi Federatsii. Prichiny stanovlenie i posledstviia' [Foreign capital in the banking sector of the Russian Federation. Causes, formation and consequences]. Moskovskii ekonomicheskii zhurnal [Moscow economic journal], [online]. Available at: https://cyberleninka.ru/article/n/inostrannyy-kapital-v-bankovskom-sektorerossiyskoy-federatsii-prichiny-stanovlenie-iposledstviya.

9. 0 vnesenii izmenenii $v$ stati 16 i 18 Federalnogo zakona "O bankakh i bankovskoi deiatelnosti" № 372 ot 14 dekabrya 2015 goda [On Amendments to Articles 16 and 18 of the Federal Law "On Banks and Banking Activities", no. 372 dated from December 14, 2015]. President Rossii, [online]. Available at: http://kremlin.ru/acts/bank/40286.

10. Panchenko, Ye., Fursova, O., Koval, V. (2012). 'Stratehii hlobalnoi konkurentospromozhnosti transnatsionalnykh bankiv' [Strategies of global competitiveness of transnational banks]. Securities market of Ukraine [Securities market of Ukraine], no. 7, pp. 73-82.

11. Pro vnesennia zmin do deiakykh zakonodavchykh aktiv Ukrainy shchodo stymuliuvannia inozemnykh investytsii ta kredytuvannia: Zakon Ukrainy vid 
27 kvitnia 2010 roku № 2155-VI [On Amendments to Certain Legislative Acts of Ukraine Concerning the Stimulation of Foreign Investments and Lending: Law of Ukraine of April 27, 2010 No. 2155-VI]. Verkhovna Rada Ukrainy, [online]. Available at: http://zakon1.rada.gov.ua/laws/show/2155-17.

12. 'Renkinh finansovoi nadiinosti bankiv Ukrainy' [Ranking of financial reliability of Ukrainian banks]. (2020). You Control, [online]. Available at: https://youcontrol.com.ua/bank-finscore/2020/3.

13. Stechyshyn, T. (2017). 'Henezys prysutnosti inozemnoho kapitalu v bankivskii systemi Ukrainy' [Genesis of the presence of foreign capital in the banking system of Ukraine]. Bankivska systema Ukrainy: stabilizatsiia ta draivery zrostannia: zbirka tez dopovidei Vseukrainskoi naukovoi internet-konferentsii (30 lystopada 2017 roku, Ternopil) [Banking system of Ukraine: stabilization and growth drivers: coll. abstracts of reports of the All-Ukrainian scientific Internet conference (November 30, 2017, Ternopil)]. Ternopil: Vector, pp. 227-231.

14. Vozna, L. B. (2013). 'Otsinka uhod zlyttiv ta pohlynan bankiv v umovakh posylennia konkurentsii' [Evaluation of mergers and acquisitions of banks in conditions of increased competition]. Biznes Inform [Business Inform], no. 9, pp. 299303.

(СДятлова Ю. В. 2021 


\section{INTERNATIONAL ASPECT OF BANKING SECTOR DEVELOPMENT: CURRENT TRENDS, FACTORS AND PROBLEMS}

\section{Diatlova Yuliia}

Doctor of Economic Sciences, Associate Professor, Donetsk State University of Management, Mariupol, Ukraine

ORCID: 0000-0001-7982-2493

yuliyadyatlova25@gmail.com

The actualization of the research is due to the need to solve an important scientific and applied problem of the development of banks with national capital in the presence of foreign capital in the country's banking sector. The purpose of the research is to systematize the newest trends in the development of the banking sector in the international and national aspects, to develop scientific provisions, to concretize factors and problems. To achieve the purpose, an evolutionary approach, abstract-logical analysis, a method of systematization and generalization were used. As a result of the research, scientific ideas about current trends and factors in the development of the banking sector were deepened. In particular, provisions on the international aspect of modern trends in the development of the banking sector have been formulated. The global trends in the expansion of financial services markets by foreign banks, the evolutionary development of transnational banks are noted. It has been established that the main trend is the growth of the presence of foreign banks in the national banking sector of countries in terms of number and assets, especially in countries with developing or transforming economies. The new stages in the development of the banking sector of Ukraine, features of trends that should be taken into account in the policy and strategy of the central bank, as well as banks with national capital, have been identified. It is shown that the lower reliability of banks with national capital in comparison with foreign banks is a destructive factor. Solving the problem will help increase confidence in domestic banks, and on this basis their development through increased assets.

Key words: banking sector; world development trends; presence of foreign banks; features in the banking sector of countries; factors of development of banks with national capital. 


\section{МЕЖДУНАРОДНЫЙ АСПЕКТ РАЗВИТИЯ БАНКОВСКОГО СЕКТОРА: СОВРЕМЕННЫЕ ТЕНДЕНЦИИ, ФАКТОРЫ И ПРОБЛЕМЫ}

\section{Дятлова Юлия Владимировна}

доктор экономических наук, доцент, Донецкий государственный университет управления, 2. Мариуполь, Украина

ORCID: 0000-0001-7982-2493

yuliyadyatlova25@gmail.com

Актуализация исследования обусловлена необходимостью решения важной научной и прикладной проблемы развития банков с национальным капиталом в присутствии иностранного капитала в банковском секторе страны. Цель исследования заключается в систематизации новейших тенденций развития банковского сектора в международном и национальном аспектах, разработке научных положений, конкретизации факторов и проблем. Для достижения цели использованы эволюционный подход, абстрактнологический анализ, метод систематизации и обобщения. В результате исследования углублены научные представления о современных тенденциях и факторах развития банковского сектора. В частности, сформулированы положения о международном аспекте современных тенденций развития банковского сектора. Отмечены мировые тенденции экспансии рынков финансовых услуг иностранными банками, эволюционное развитие транснациональных банков. Установлено, что основной тенденцией является рост присутствия иностранных банков в национальном банковском секторе стран по количеству и активам, особенно в странах с развивающейся или трансформирующейся экономикой. Определены новые этапы развития банковского сектора Украины, особенности тенденций, которые должны быть учтены в политике и стратегии центрального банка, а также банками с отечественным капиталом. Показано, что более низкая надежность банков с отечественным капиталом по сравнению с иностранными банками является деструктивным фактором. Решение проблемы будет способствовать повышению доверия к отечественным банкам, а на этой основе их развитию из-за увеличения активов.

Ключевые слова: банковский сектор; мировые тенденции развития; присутствие иностранных банков; особенности в банковском секторе стран; факторы развития банков с национальным капиталом.

С.Дятлова Ю. В. 2021 